\title{
A TOXIC CYANOBACTERIAL BLOOM IN AN URBAN COASTAL LAKE, RIO GRANDE DO SUL STATE, SOUTHERN BRAZIL
}

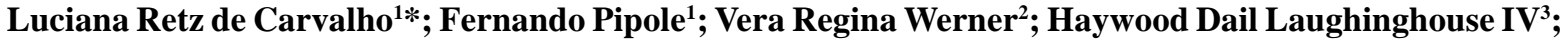 Antonio Carlos M. de Camargo ${ }^{4}$; Marisa Rangel ${ }^{5}$; Katsuhiro Konno ${ }^{4}$; Célia Leite Sant'Anna ${ }^{1}$}

\author{
${ }^{1}$ Seção de Ficologia, Instituto de Botânica, São Paulo, SP, Brasil; ${ }^{2}$ Museu de Ciências Naturais, Fundação Zoobotânica do Rio \\ Grande do Sul, Porto Alegre, RS, Brasil; ${ }^{3}$ Department of Biology, John Carroll University, University Heights, OH, USA; \\ ${ }^{4}$ Centro de Toxinologia Aplicada, Instituto Butantan, São Paulo, SP, Brasil; ${ }^{5}$ Seção de Anatomopatologia, Instituto Butantan, \\ São Paulo, SP, Brasil
}

Submitted: July 17, 2007; Returned to authors for corrections: December 04, 2007; Approved: November 02, 2008.

\begin{abstract}
Reports of cyanobacterial blooms developing worldwide have considerably increased, and, in most cases, the predominant toxins are microcystins. The present study reports a cyanobacterial bloom in Lake Violão, Torres, Rio Grande do Sul State, in January 2005. Samples collected on January 13, 2005, were submitted to taxonomical, toxicological, and chemical studies. The taxonomical analysis showed many different species of cyanobacteria, and that Microcystis protocystis and Sphaerocavum cf. brasiliense were dominant. Besides these, Microcystis panniformis, Anabaena oumiana, Cylindrospermopsis raciborskii, and Anabaenopsis elenkinii f. circularis were also present. The toxicity of the bloom was confirmed through intraperitoneal tests in mice, and chemical analyses of bloom extracts showed that the major substance was anabaenopeptin F, followed by anabaenopeptin B, microcystin-LR, and microcystin-RR.
\end{abstract}

Key words: Cyanobacteria, blooms, Microcystis protocystis, anabaenopeptins, microcystins

\section{INTRODUCTION}

Cyanobacterial blooms are the massive proliferation of cyanobacteria in aquatic environments, when environmental conditions (such as light, temperature, nutrients, water column stability, and $\mathrm{pH}$ ) are suitable for their growth, and one of the major consequences of aquatic system eutrophication $(1,4,41)$.

In Brazil, where these events are very frequent, the most common freshwater bloom forming genera are Microcystis, Anabaena, Aphanizomenon, Planktothrix, and Cylindrospermopsis, which is also the most studied cyanobacterial group $(3,6,18,24$, $28,33,38,40,43,47)$.

Cyanobacteria produce an impressive diversity of secondary metabolites, where the major parts are identified as peptides, possessing peptidic substructures, or alkaloids $(11,13)$.

Microcystis produces microcystins, potent cyclic hepatotoxins, which inhibit specific serine/threonine protein phosphatases (PP1 and PP2A), and are powerful tumor promoters $(8,26)$. Microcystins have been responsible for the death of animals and humans, and are the most frequent toxin found in water bloom surveys, present in more than $60 \%$ of all samples (42).

Besides these peptides, various other linear and cyclic oligopeptides such as aeruginosins, microginins, micropeptins, aeruginopeptins, and anabaenopeptins are found within this genus. These oligopeptides are protease inhibitors $(15,17,31$, 32,36).

Anabaena synthesizes neurotoxic (anatoxin-a, anatoxin$\mathrm{a}(\mathrm{S})$, and saxitoxins) and cytotoxic (cylindrospermopsin) alkaloids and hepatotoxic peptides (microcystins) together with non-toxic oligopeptides like the well-known anabaenopeptins (8). Anabaenopeptins $\mathrm{B}$ and $\mathrm{F}$ are the most common compounds among the anabaenopeptin class. They are 19-membered cyclic depsipeptides that possess ureido linkage and have bioactive

*Corresponding Author. Mailing address: Av Dr. Miguel Estéfano, 3687, 04301-012, São Paulo, SP, Brasil. Tel.: (+5511) 5073-6300 Fax: (+5511) 5073 3678. E-mail: 1retz@uol.com.br 
properties: anabaenopeptin B showed weak relaxation activity to norepinephrine-induced constriction of rat aortic preparations (14) and anabaenopeptin $\mathrm{F}$ is an inhibitor of protein phosphatases PP1 and PP2A $(37,39)$.

Aphanizomenon mainly produces the alkaloids, anatoxin-a, saxitoxin, and cylindrospermopsin; Cylindrospermopsis synthesizes cylindrospermopsins and saxitoxins; and Oscillatoria, microcystins and anatoxin-a (7). According to Codd et al. (2005) (5), Planktothrix produces microcystins and saxitoxins.

Therefore, it is expected that blooms made up of different cyanobacterial species, would contain a wide variety of bioactive/ non-bioactive compounds. Thus, in this paper the occurrence of a toxic bloom formed by several cyanobacteria species and the identification of its major metabolites were described.

\section{MATERIALAND METHODS}

\section{Study area}

Lake Violão is located in the extreme north of the lagoonal system found in the Coastal Plain of Rio Grande do Sul State, southern Brazil (29²0'44" S and 4943' 58" W). This subtropical freshwater ecosystem is located near the city center of Torres, between the basaltic counterforts and sedimentary plains of the Mampituba River. The lake's surface area is $14 \mathrm{~km}^{2}$ and the average depth is $2 \mathrm{~m}$. All along the period of bloom permanence (November 2004 to April 2005), the maximum and minimum $\mathrm{pH}$ registered in the lake were 7.5 and 8.5 , respectively; water temperature ranged from 24.8 to $32^{\circ} \mathrm{C}$, and the conductivity from 241 to $367 \mathrm{mS} / \mathrm{cm}$.

It has a diversity of aquatic macrophytes, especially waterhyacinths (Eichhornia crassipes) and aquatic grasses, mainly along the margins. The lake is a tourist attraction, used for recreation, fishing, and water sports.

\section{Sampling and taxonomical studies}

The samples studied for taxonomical, chemical, and toxicological analyses were collected on January 13, 2005, near the central zone of the lake. Material from cyanobacterial scum was collected using a flask, from the top of the water column, and also with a plankton net (25 $\mu \mathrm{m}$ mesh), around noon (12:0013:00 hours). A set of samples was used to study the cyanobacterial composition. They were preserved with $4 \%$ formaldehyde and included in the Prof. Dr. Alarich R.H. Schültz Herbarium (HAS), Brazil. The material was studied using light microscopes. The photos were taken using a Zeiss Axioplan-2 microscope equipped with phase contrast and Optovar lens. The classification system by Komárek \& Anagnostidis (1989, 1999 , and 2005) $(19,20,21)$ was adopted.

\section{Mouse bioassay}

Estimation of the minimum $100 \%$ lethal dose $\left(\mathrm{MLD}_{100}\right)$ was carried out with male mice "Swiss-Webster", 19-21 g, injected intraperitoneally (i.p.) with extract made of freeze dried cells extracted by sonication (20 min., $50 \mathrm{~W}$ ) in sterile $0.9 \% \mathrm{NaCl}$ solution $(n=2)$. Time to death, signs of poisoning, and other symptoms were observed up to $72 \mathrm{~h}$ after injection. Animals killed by extract injection were necropsied to observ their livers.

\section{Chemical analysis.}

Preparation of cyanobacterial extracts. Freeze-dried cells (8.1841 g) were extracted with $0.1 \mathrm{M}$ aqueous acetic acid (4 x 50 $\mathrm{mL}$ ) by sonication $(4 \mathrm{x}, 20 \mathrm{~min} ., 50 \mathrm{~W})(34)$. The combined extracts were centrifuged (1.830 x g, $50 \mathrm{~min})$, and the supernatant was collected, and then freeze-dried. The dried material (1.4438 g) was applied on a preconditioned $\mathrm{C}_{18}$ silica gel column (Bond Elut) that was eluted using a gradient profile as follows: (1) TFA $0.1 \%$ (112.5 mL), (2) TFA 0.1\%/ACN 80:20(v/v) (112.5 mL), (3) TFA 0.1\%/ACN 50:50 (v/v) (112.5 mL), (4) TFA 0.1\%/ACN 10:90 (v:v) $(112.5 \mathrm{~mL})$. Each eluent from the step-gradient sequence was collected separately in three subfractions of $37.5 \mathrm{~mL}$, summing 12 subfractions. These twelve subfractions were then lyophilized or evaporated to dryness, and analyzed for toxin and other peptide content using a matrix-assisted laser desorption/ionization time-of-flight mass spectrometry (MALDI-TOF MS) and ESI-Q-TOF MS.

Mass spectrometry analyses. MALDI-TOF MS analysis was performed on an Ettan MALDI-TOF/Pro (Amersham Biosciences, Sweden) equipped with $337 \mathrm{~nm}$ pulsed nitrogen laser under reflector mode. The accelerating voltage was $20 \mathrm{kV}$. Matrix $\alpha$-cyano-4-hydroxycinnamic acid (Aldrich) was prepared at a concentration of $10 \mathrm{mg} / \mathrm{ml}$ in $1: 1 \mathrm{CH}_{3} \mathrm{CN} / 0.1 \%$ TFA. External calibration was performed with angiotensin I $(\mathrm{m} / z$ 1296.69, monoisotopic, Sigma) and human ACTH fragment 18-39 ( $\mathrm{m} / \mathrm{z}$ 2465.19, monoisotopic, Sigma). The sample solution $(0.5 \mu \mathrm{l})$ dropped onto the MALDI sample plate was added to the matrix solution $(0.5 \mu \mathrm{l})$, and allowed to dry at room temperature.

Structural analysis by tandem mass spectrometry (MS/MS) was carried out on a Q-TOF Ultima API, fitted with an electrospray ion source (Micromass, Manchester UK) under positive ionization mode. The aqueous sample solutions (2-5 $\mu \mathrm{l})$ were directly injected using a Rheodyne 7010 sample loop coupled to a LC-10A VP Shimadzu pump at $20 \mu \mathrm{l} / \mathrm{min}$ constant flow rate. External calibration was performed with NaI (Fluka) over $m / z$ 100-2000. For MS/MS measurements, collision energy ranged from 18 to 45 and the precursor ions were selected under a $1 \mathrm{~m} / \mathrm{z}$ window. Structures were analyzed manually from the MS/MS spectra.

HPLC analysis. The lyophilized samples were dissolved in 1:1 $\mathrm{CH}_{3} \mathrm{CN} / \mathrm{H}_{2} \mathrm{O}$ and subjected to reverse-phase HPLC (Shimadzu Corp., Kyoto, Japan) using CAPCELL PAK C 18,6 x 150 mm (SHISEIDO Co., Ltd., Tokyo, Japan) with a linear gradient from $15 \%$ to $65 \% \mathrm{CH}_{3} \mathrm{CN} / \mathrm{H}_{2} \mathrm{O} / 0.1 \%$ TFA at a flow rate of $1 \mathrm{ml} / \mathrm{min}$ 
over $25 \mathrm{~min}$. UV absorbance was monitored at $215 \mathrm{~nm}$. Each peak was manually fractionated and freeze-dried. The lyophilized samples were dissolved in water and subjected to mass spectrometry analyses.

\section{RESULTS AND DISCUSSION}

Due to recent accelerated urban growth, Lake Violão has been suffering a series of impacts such as input of waste and trash, which compromise water quality, turning the environment into one that is prone to form cyanobacterial blooms, as already shown for different freshwater systems $(16,30)$.
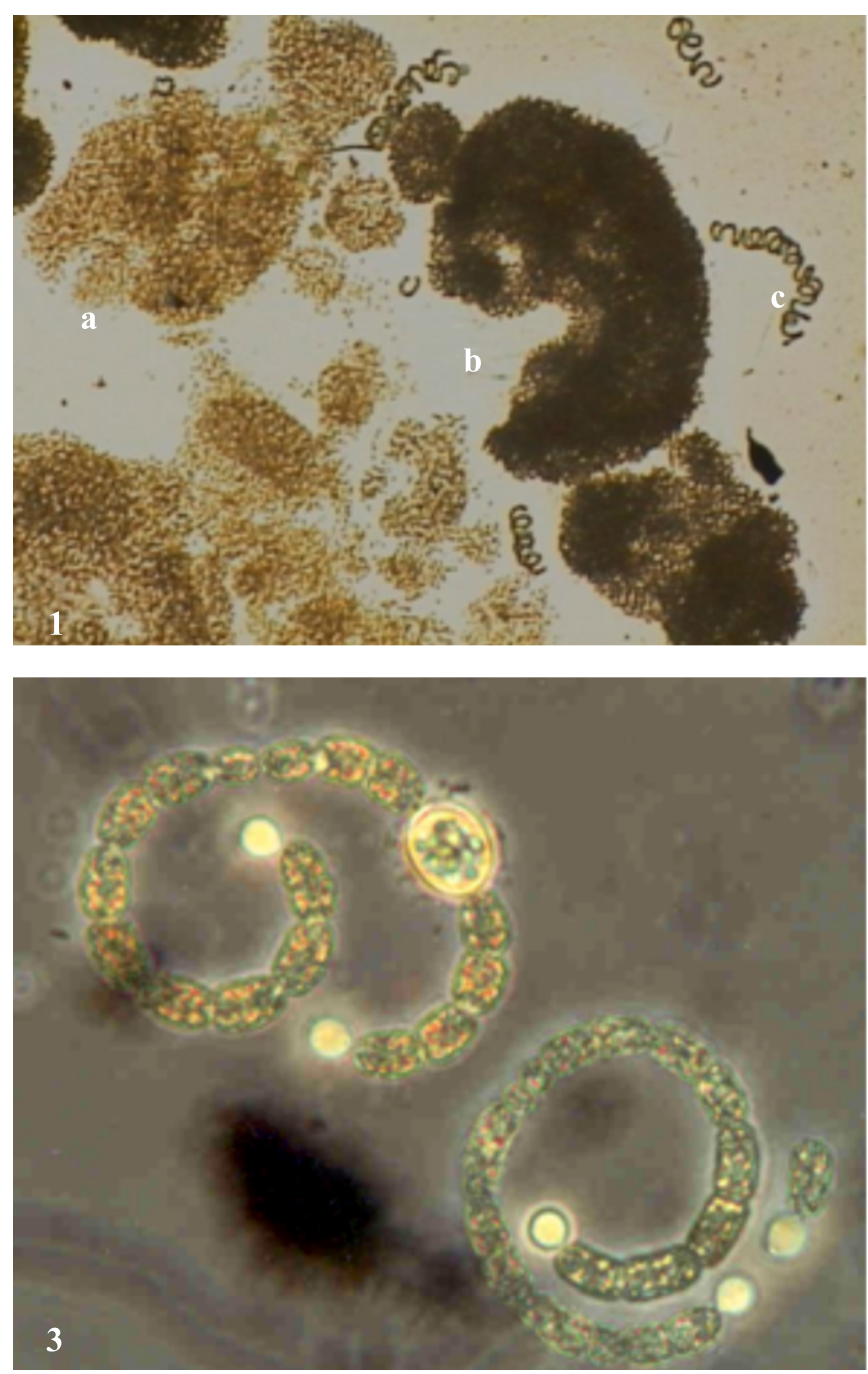

The studied bloom was formed by many different species of cyanobacteria (Figs. 1-4), where Microcystis protocystis and Sphaerocavum cf. brasiliense were predominant. Besides this, in the samples used for chemical and toxicological analyses, Anabaena oumiana, Cylindrospermopsis raciborskii Anabaenopsis elenkinii f. circularis, and Aphanothece stagnina were also present. Sphaerocavum cf. brasiliense is a widespread Brazilian species that usually occurs in eutrophic waters together with Microcystis blooms, which has not yet been cited for producing toxins (1).

The environmental conditions, like alkaline $\mathrm{pH}(7.5$ - 8.5), electrical conductivity from 241 to $367 \mu \mathrm{S} / \mathrm{cm}$, and temperature
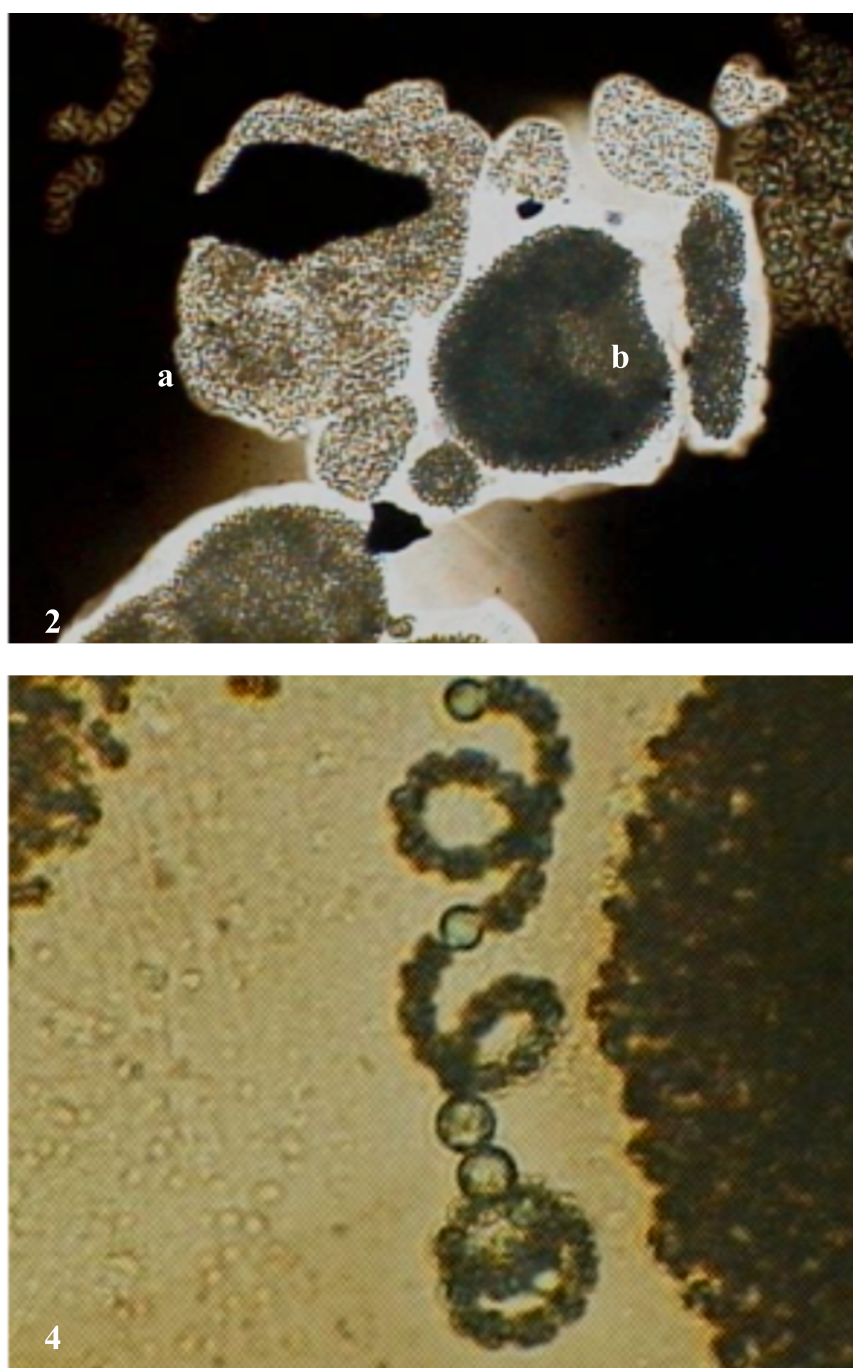

Figures 1-4. Microphotographs of species found in the cyanobacterial bloom at Lake Violão, Brazil. 1. a) Microcystis protocystis, b) Sphaerocavum cf. brasiliense, and c) Anabaena oumiana; 2. a) Microcystis protocystis, b) Sphaerocavum cf. brasiliense; 3. Anabaena oumiana filament between two colonies of Sphaerocavum cf. brasiliense; 4. Detail of Anabaenopsis circularis $\mathrm{f}$. elenkinii. (Photos by H.D. Laughinghouse IV and V.R. Werner). 
between 24.8 and $32^{\circ} \mathrm{C}$, are similar to those occurring during blooms containing microcystin development $(6,25,27,40,47)$.

In the mouse bioassay, the extract of lyophilized cells presented a $\mathrm{MLD}_{100}$ of ca. $875 \mathrm{mg} \cdot \mathrm{kg}^{-1}$ body weight. Mouse deaths occurred within $50 \mathrm{~min}-1.5 \mathrm{~h}$; the livers were swollen, blood-filled, and larger when compared to control, showing typical signs of hepatotoxic intoxication.

According to Lawton et al. (1994) classification, this bloom presented low toxicity; in general, the $\mathrm{LD}_{50}$ toxicity values of Brazilian natural blooms containing microcystins ranged from 35.5 to $445.45 \mathrm{mg} \cdot \mathrm{kg}^{-1}(25,29,33,40,47)$ and can be classified among the most toxic blooms. For the isolated strains of microcystin producers, the lowest $\mathrm{LD}_{50}$ value is $13.7 \mathrm{mg} \cdot \mathrm{kg}^{-1}$ and the highest is $742 \mathrm{mg} \cdot \mathrm{kg}^{-1}(1,22,33,43,48)$.

MALDI-TOF MS analysis obtained from the twelve subfractions showed that cyanotoxins (microcystins) eluted from the $\mathrm{C}_{18}$ silica gel column in TFA 0.1\%/ACN 50:50 (v/v) and TFA $0.1 \% / A C N$ 10:90 (v:v), could be identified by their protonated, monoisotopic mass $(\mathrm{M}+\mathrm{H})^{+}$as microcystin-LR $(\mathrm{m} / \mathrm{z}$ 995.54) and microcystin-RR ( $\mathrm{m} / \mathrm{z}$ 1038.60) (Fig. 5, mass spectrum a, peaks 7 and $\mathbf{8}$, respectively). The mass spectrum a showed hitherto the presence of anabaenopeptins B and F, and four unidentified molecular ion peaks at $m / z$ 600.26, 613.24, 932.44 and $948.46[\mathrm{M}+\mathrm{H}]^{+}$(Fig. 5, mass spectrum a, peaks 1 6). Table 1 summarizes these compounds.

The mass spectra b, c, and d (Fig. 5) were very similar: within them only anabaenopeptins B and F and microcystins-LR and RR are present. In spectra $\mathbf{d}$ and e (Fig. 5), corresponding to the subfractions 11 and 12, microcystin-RR does not show up anymore.

The diagnostic ions observed in the ESI-MSMS experiments (46) for subfractions 7-12 (Fig. 6: spectra $\mathbf{g}-\mathbf{j}$ ) corroborated with the identification of peaks $3,4,7$, and $\mathbf{8}$ (showed at Fig. 5, spectra a - f) as anabaenopeptin $\mathrm{B}\left[(\mathrm{M}+\mathrm{H})^{+}=837.5\right]$ and $\mathrm{F}\left[(\mathrm{M}+\mathrm{H})^{+}=851.5\right](10)$ and microcystin-LR $\left[(\mathrm{M}+\mathrm{H})^{+} 995.6\right]$ and $\mathrm{RR}\left[(\mathrm{M}+\mathrm{H})^{+}=1038.6\right]$, respectively (Tables $\left.2-4\right)$.

The twelve subfrations were also analyzed by HPLC. The profile from fraction 8 (Fig. 1, spectra b) was shown in Fig. 7. The HPLC and mass spectra data indicated that there were higher
Table 2. Assignment of ESI-MS/MS for anabaenopeptins B and $\mathrm{F}$.

\begin{tabular}{|c|c|c|}
\hline Fragment & $\begin{array}{c}\text { Anabae- } \\
\text { nopeptin B } \\
m / z\end{array}$ & $\begin{array}{c}\text { Anabae- } \\
\text { nopeptin } \mathrm{F} \\
\mathrm{m} / z\end{array}$ \\
\hline$[\mathrm{Arg}+\mathrm{H}]^{+}$ & 175.13 & 175.13 \\
\hline$[\mathrm{Arg}+\mathrm{CO}]^{+}$ & 201.10 & 201.10 \\
\hline$[\mathrm{Phe}+\mathrm{MeAla}+\mathrm{H}]^{+}$ & 233.14 & 233.14 \\
\hline$[\mathrm{MeAla}+\mathrm{Hty}+\mathrm{H}]^{+}$ & 263.15 & 263.16 \\
\hline$[\mathrm{Hty}+\mathrm{Val}+\mathrm{H}]^{+}$ & 362.23 & - \\
\hline$[\mathrm{Hty}+\mathrm{Ile}+\mathrm{H}]^{+}$ & - & 376.25 \\
\hline$[\mathrm{Val}+\mathrm{Lys}+\mathrm{Phe}+\mathrm{MeAla}+\mathrm{H}]^{+}$ & 460.31 & - \\
\hline$[\mathrm{Ile}+\mathrm{Lys}+\mathrm{Phe}+\mathrm{MeAla}+\mathrm{H}]^{+}$ & - & 474.34 \\
\hline$[\mathrm{Phe}+\mathrm{MeAla}+\mathrm{Hty}+\mathrm{Val}+\mathrm{H}]^{+}$ & 509.29 & - \\
\hline$[\mathrm{Phe}+\mathrm{MeAla}+\mathrm{Hty}+\mathrm{Ile}+\mathrm{H}]^{+}$ & - & 523.33 \\
\hline$[\mathrm{Phe}+\mathrm{MeAla}+\mathrm{Hty}+\mathrm{Val}+\mathrm{Lys}+\mathrm{H}]^{+}$ & 637.39 & - \\
\hline$[\mathrm{Phe}+\mathrm{MeAla}+\mathrm{Hty}+\mathrm{Ile}+\mathrm{Lys}+\mathrm{H}]^{+}$ & - & 651.41 \\
\hline$[\mathrm{Phe}+\mathrm{MeAla}+\mathrm{Hty}+\mathrm{Val}+\mathrm{Lys}+\mathrm{CO}]^{+}$ & 663.40 & - \\
\hline$[\mathrm{Phe}+\mathrm{MeAla}+\mathrm{Hty}+\mathrm{Ile}+\mathrm{Lys}+\mathrm{CO}]^{+}$ & - & 677.40 \\
\hline$[\mathrm{M}+\mathrm{H}]^{+}$ & 837.47 & 851.49 \\
\hline
\end{tabular}

Table 3. Assignment of ESI-MS/MS for microcystin-LR.

\begin{tabular}{cl}
\hline$m / z$ & \multicolumn{1}{c}{ Fragment } \\
\hline 135.10 & (Adda fragment) $\left(\mathrm{Ph}-\mathrm{CH}_{2}-\mathrm{CH}-\mathrm{OCH}_{3}\right)$ \\
155.10 & Mdha+Ala+H \\
213.11 & Glu+Mdha+H \\
268.19 & Mdha+Ala+Leu+H \\
375.23 & Adda fragment + Glu+Mdha \\
397.27 & Mdha+Ala+Leu+MeAsp+H \\
470.32 & Arg+Adda+H \\
553.39 & Mdha+Ala+Leu+MeAsp+Arg+H \\
599.42 & MeAsp+Arg+Adda+Glu+H \\
682.44 & Glu+Mdha+Ala+Leu+MeAsp+Arg+H \\
967.69 & {$[\mathrm{M}+\mathrm{H}-\mathrm{CO}]^{+}$} \\
995.65 & $\mathrm{M}+\mathrm{H}$ \\
\hline
\end{tabular}

Table 1. Peptides detected in fractions 7-12 (Ion m/z).

\begin{tabular}{ccccccccc}
\hline \multirow{2}{*}{ Subfraction } & \multicolumn{7}{c}{ Peaks } \\
\cline { 2 - 8 } & $\mathbf{1}$ & $\mathbf{2}$ & $\mathbf{3}$ & $\mathbf{4}$ & $\mathbf{5}$ & $\mathbf{6}$ & $\mathbf{7}$ & $\mathbf{8}$ \\
\hline $\mathbf{7}$ & 599.26 & 613.24 & 837.45 & 851.47 & 932.45 & 948.46 & 995.54 & 1038.60 \\
$\mathbf{8}$ & & & 837.45 & 851.47 & & & 995.54 & 1038.60 \\
$\mathbf{9}$ & & & 837.45 & 851.47 & & 995.54 & 1038.60 \\
$\mathbf{1 0}$ & & & 837.45 & 851.47 & & 995.54 & 1038.60 & 995.54 \\
$\mathbf{1 1}$ & & & 837.45 & 851.47 & & & 995.54 \\
\hline
\end{tabular}




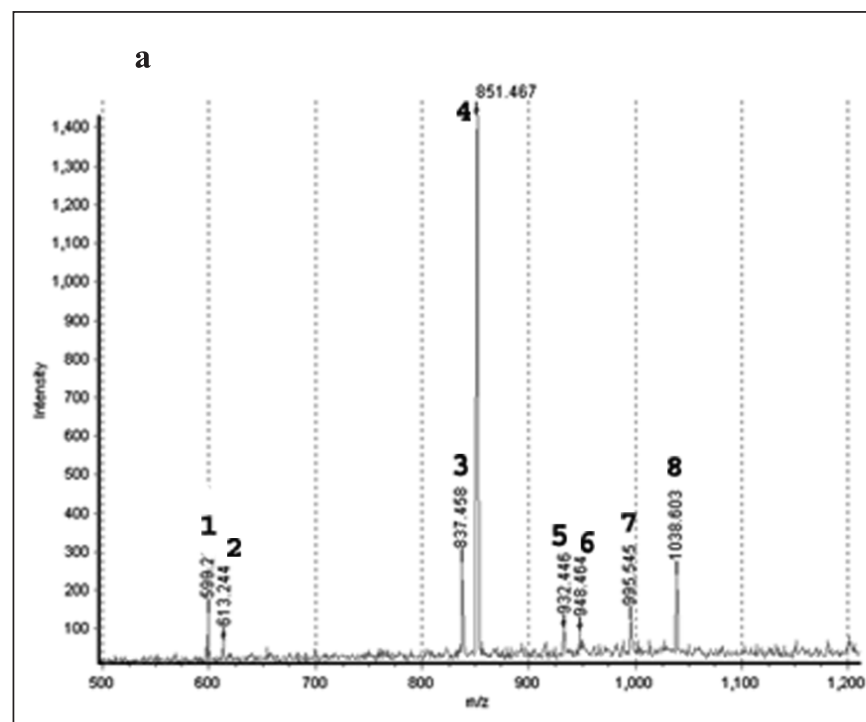

b
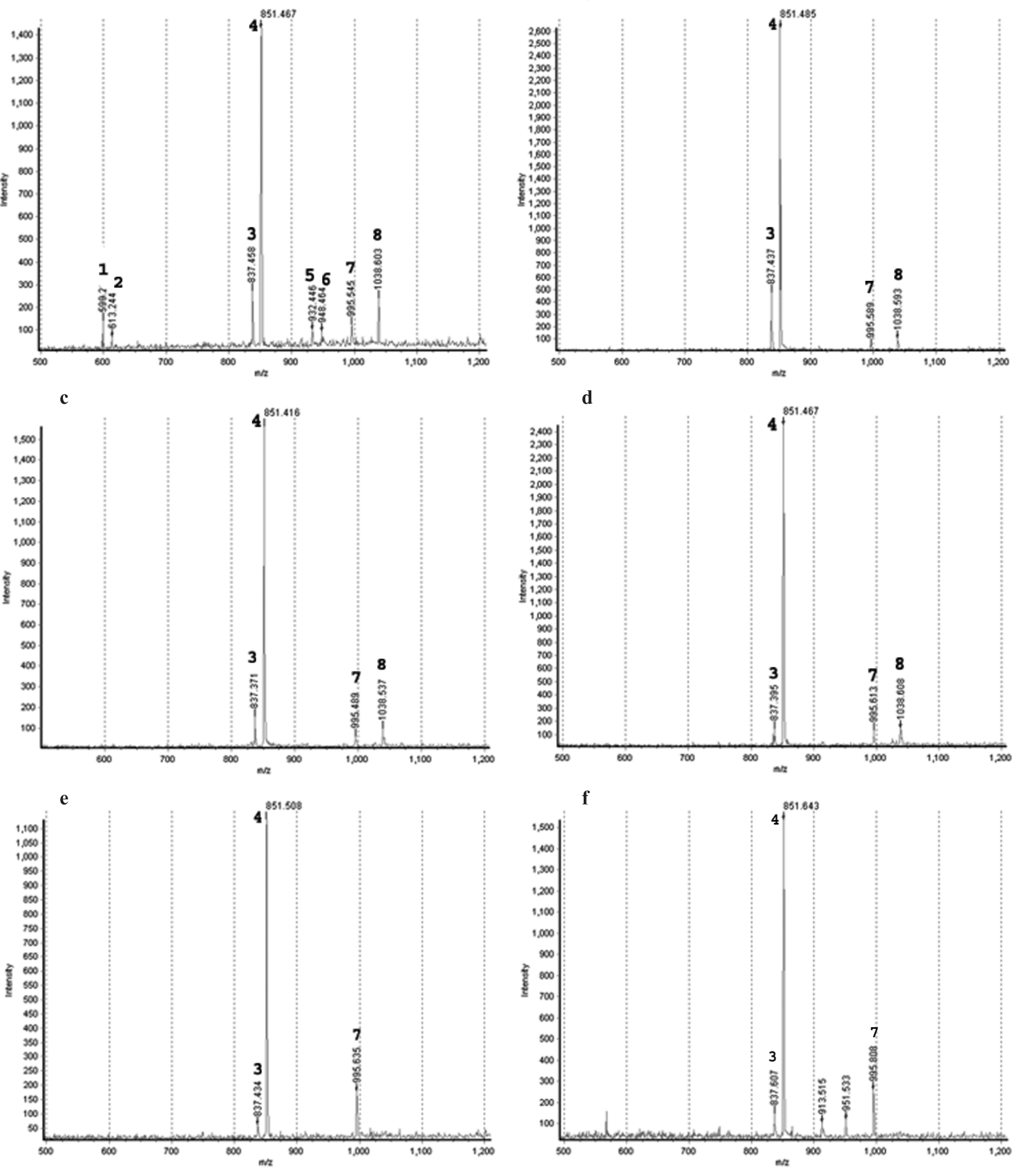

Figure 5. MALDI-TOF mass spectra of the peptidic fractions 7 to 12 (corresponding to $\mathbf{a}$ to $\mathbf{f}$ spectra) of Lake Violão bloom. Numbers above masses designate peptides. 
g

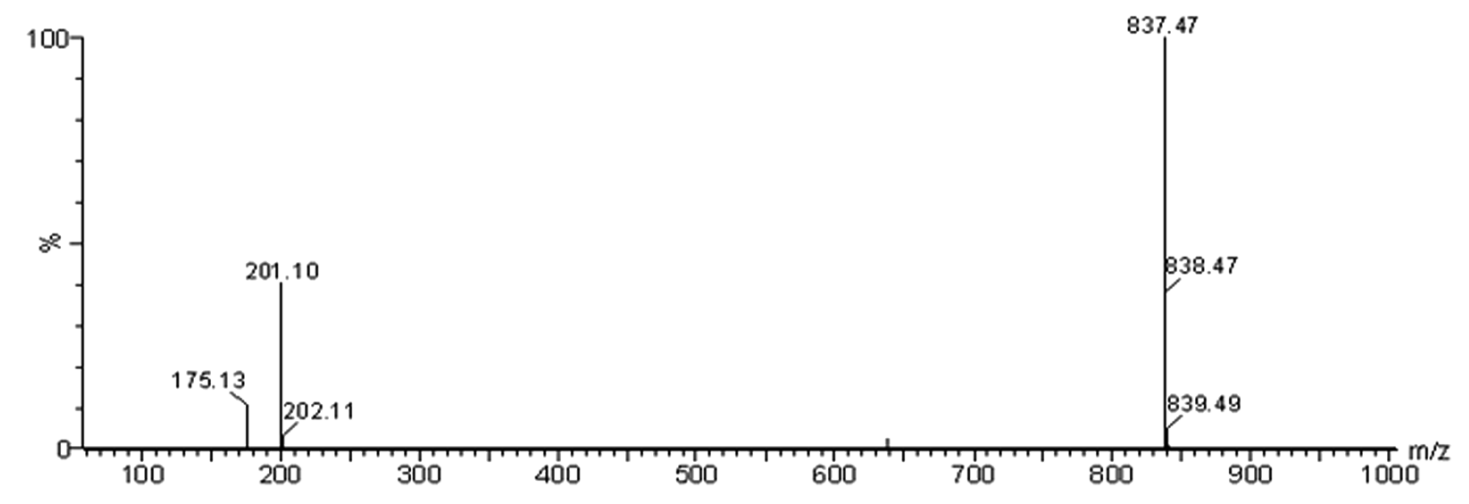

h

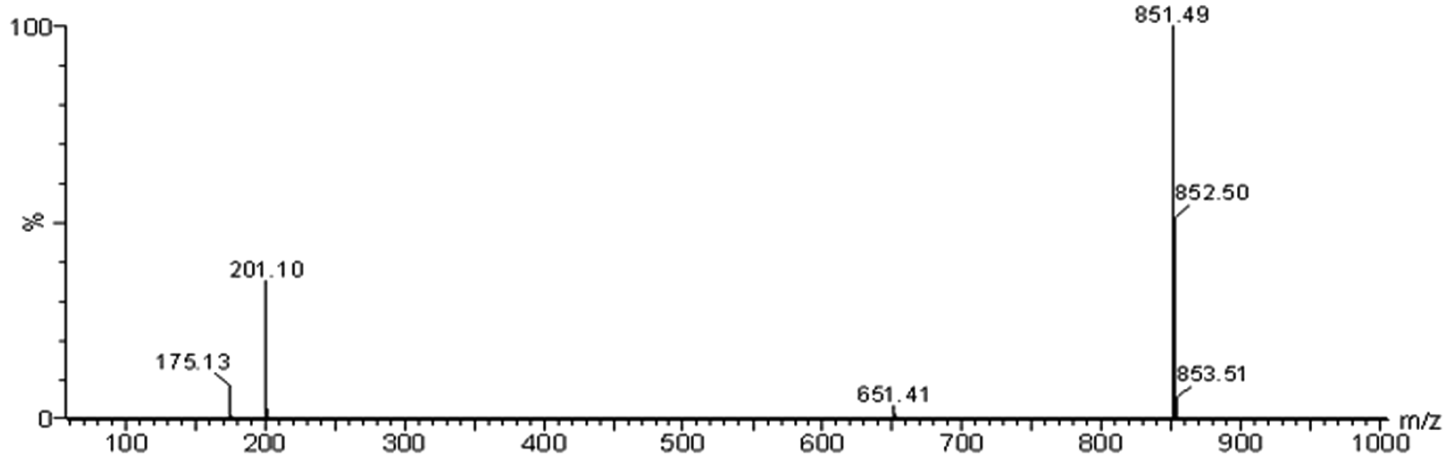

i

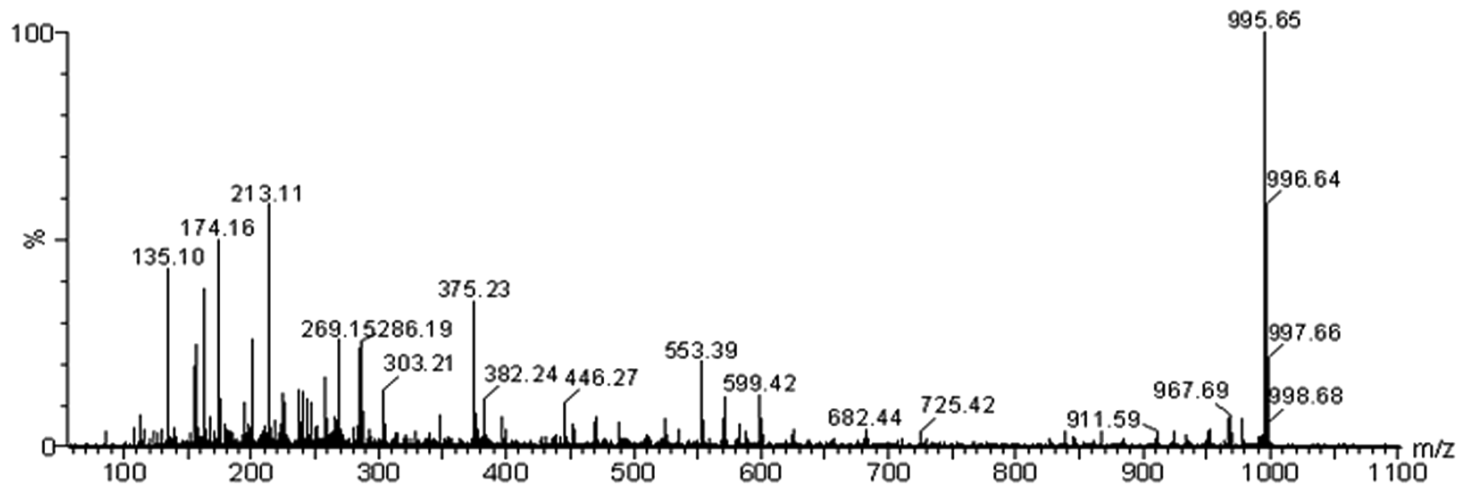

j

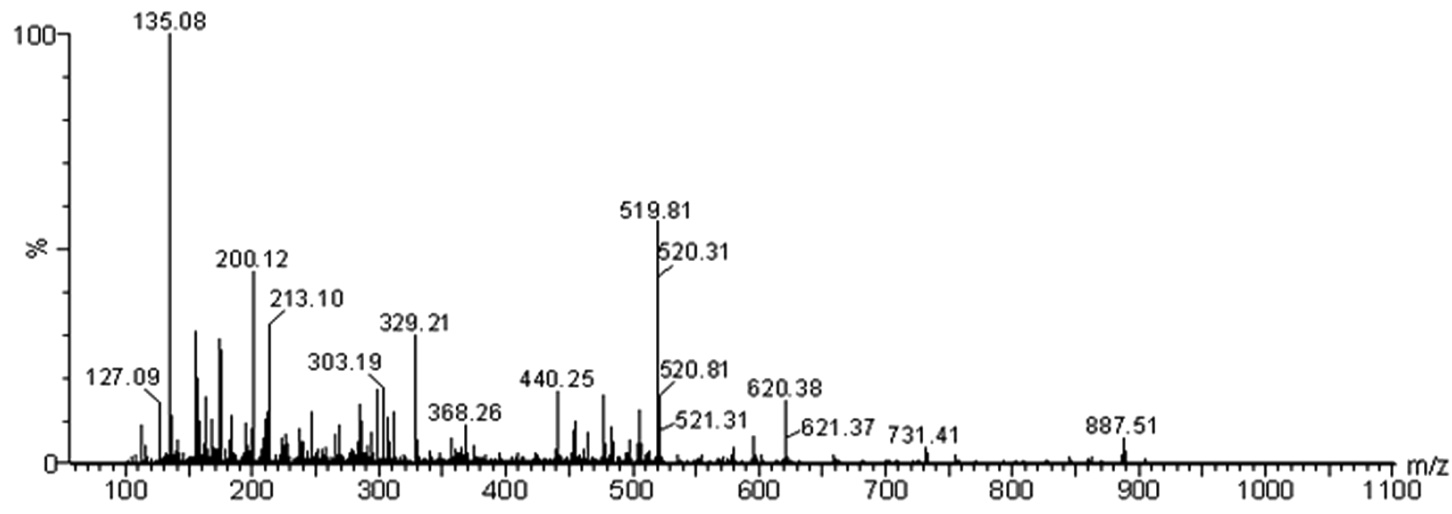

Figure 6. Anabaenopeptins B and F, and microcystins-LR and RR mass spectra data fragmentation (spectra $\mathbf{g}$ to $\mathbf{j}$, respectively). 
Table 4. Assignment of ESI-MS/MS for microcystin-RR.

\begin{tabular}{cl}
\hline$m / z$ & Fragment \\
\hline 135.08 & (Adda fragment) $\left(\mathrm{Ph}-\mathrm{CH}_{2}-\mathrm{CH}-\mathrm{OCH}_{3}\right)$ \\
155.09 & Mdha+Ala+H \\
213.10 & Glu+Mdha+H \\
303.19 & MeAsp+Arg+NH \\
311.20 & Mdha+Ala+Arg+H \\
375.21 & Adda fragment+Glu+Mdha \\
440.25 & Mdha+Ala+Arg+MeAsp+H \\
519.81 & {$[\mathrm{M}+2 \mathrm{H}]^{2+}$} \\
\hline
\end{tabular}

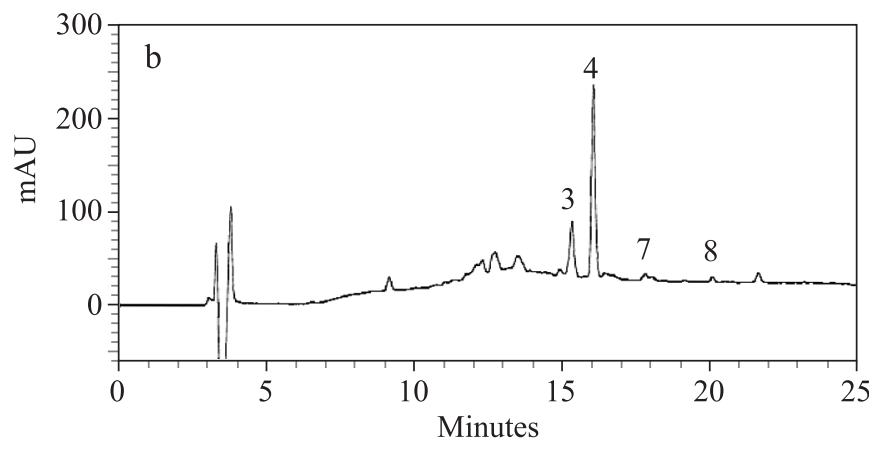

Figure 7. HPLC fraction $b$ profile.

amounts of anabaenopeptin $\mathrm{F}$ in all fractions and relatively lower amounts of microcystins. Despite the fact that anabaenopeptin F was the major compound, the water bloom in Lake Violão was toxic. The co-occurrence of cyanotoxins and several other oligopeptides that have biological activities is well documented; microcystins were reported to occur simultaneously with anabaenopeptins, microginins, micropeptins, and aeruginosins $(9,12,35,44,45)$.

We have found that the Lake Violão bloom sample also contained traces of other microcystins and anabaenopeptins, besides microginins, aeruginosins and cyanopeptolins. Identification and characterization of these peptides are underway. Reports about the co-occurrence of a great variety of oligopeptides in cyanobacterial blooms are becoming more frequently published $(9,35,44,45)$.

These studies supplement those which focus only on microcystins in the blooms, as being the most important metabolites produced by cyanobacteria (44). Harada (2004)(13) raised the hypothesis that there are oligopeptides able to potentialize the toxic effects of microcystins, based on the different reactions of mammals receiving purified microcystins and those receiving integral cellular material.

\section{ACKNOWLEDGEMENTS}

To FAPESP (Project $n^{\circ}$ 03/02098-6) and CNPq (Grant $n^{\circ}$ 308086/2004-0) for the financial support, to CNPq for the fellowship to H.D. Laughinghouse IV (Grant 104716/2005-3), and to Nabor de Azevedo Guazzelli for the support during some sampling and help on information about the lake.

\section{RESUMO}

\section{Uma floração de cianobacterias em um lago costeiro urbano, Rio Grande do Sul, Brasil}

O número de relatos de ocorrências de florações de cianobactérias em todo o mundo vem aumentando consideravelmente e na maioria desses episódios, as toxinas dominantes são as microcistinas. $\mathrm{O}$ presente estudo relata a ocorrência de floração na Lagoa do Violão, município de Torres, RS, em janeiro de 2005. As amostras coletadas em 13/01/2005 foram submetidas a estudos taxonômicos, toxicológicos e químicos. O exame microscópico do fitoplancton mostrou a dominância das espécies Microcystis protocystis e Sphaerocavum cf. brasiliense; foram observadas, também, Microcystis panniformis, Anabaena oumiana, Cylindrospermopsis raciborskii e Anabaenopsis elenkinii f. circularis. A toxicidade da floração foi confirmada através de ensaio intraperitonial em camundongos e a análise química de extratos obtidos da biomassa liofilizada mostrou que a substância majoritária era a anabaenopeptina $\mathrm{F}$, seguida por anabaenopeptina $B$, microcistina-LR e microcistina-RR.

Palavras-chave: cianobactérias, florações, Microcystis protocystis, anabaenopeptina, microcistina.

\section{REFERENCES}

1. Azevedo, S.M.F.O. (1998). Toxinas de cianobactérias: causas e conseqüências para a saúde pública. Medicina on line, 3 (1), 1-19.

2. Azevedo, M.T.P.; Sant'Anna, C.L. (2003). Sphaerocavum brasiliense, a new planktic genus and species of Cyanobacteria from reservoirs of São Paulo State, Brazil. Algol. Stud., 109, 79 92.

3. Branco, C.W.; Senna, P.A.C. (1994). Factors influencing the development of Cylindrospermopsis raciborskii and Microcystis aeruginosa in Paranoá Reservoir, Brasília, Brazil. Algol. Stud., 75, 85-96.

4. Brandão, L.H.; Domingos, P. (2006). Environmental factors for toxic cyanobacteria bloom. Saúde \& Ambiente em Revista, 1 (2) 40-50.

5. Codd, G.A.; Lindsay, J.; Young, F.M.; Morrison, L.F.; Metcalf, J.S (2005). Harmful cyanobacteria. From mass mortalities to management measures. In: Huisman, J., Matthijs, C.P., Visser, M. (eds.). Harmful cyanobacteria. Aquatic Ecology Series. Springer, Netherlands, p. 1-23.

6. Costa, I.A.S.; Azevedo, S.M.F.O.; Senna, P.A.C.; Bernardo, R.R.; Costa, S.M.; Chellappa, N.T. (2006). Occurrence of toxin-producing 
cyanobacteria blooms in a Brazilian semiarid reservoir. Braz. J. Biol., 66(1B), 211-219.

7. Falconer, I.R. (2005). Toxic Cyanobacteria and their identification. In: Falconer, I. (ed.). Cyanobacterial toxins of drinking water supplies. CRC Press, Boca Raton, USA, p. 9-23.

8. Falconer, I.R.; Humpage, A.R. (1996). Tumour promotion by cyanobacterial toxins. Phycologia, 35 (6), 74-79.

9. Fastner, J.; Erhard, M.; von Döhren, H. (2001). Determination of oligopeptide diversity within a natural population of Microcystis spp. (Cyanobacteria) by typing single colonies by matrix-assisted laser desorption ionization-time of flight mass spectrometry. Appl. Environ. Microbiol., 67, 5069-5076.

10. Forchert, A.; Neumann, U.; Papendorf, O. (2001). New cyanobacterial substances with bioactive properties. In: Chorus, I. (ed). Cyanotoxins. Occurrence, causes, consequences. Springer-Verlag, Berlin, Deutschland, p. 295-315.

11. Fujii, K.; Sivonen, K.; Nakano, T.; Harada, K.-i. (2004). Structural elucidation of cyanobacterial peptides encoded by peptide synthetase gene in Anabaena species. Tetrahedron, 58, 6863-6871.

12. Fujii, K.-i.; Harada, K.-i.; Suzuki, M.; Kondo, F.; Ikai, Y.; Oka, H.; Carmichael, W.W.; Sivonen, K. (1996). Occurrence of novel cyclic peptides together with microcystins from toxic cyanobacteria, Anabaena species. In: Yasumoto, T., Oshima, Y., Fukuyo, Y. (eds). Harmful and toxic algal blooms. Intergovernmental Oceanographic Commission of UNESCO, Paris, France, p. 559-562.

13. Harada, K-i. (2004). Production of secondary metabolites by freshwater cyanobacteria. Chem. Pharm. Bull., 52(8), 889-899.

14. Harada, K-i.; Fujii, K.; Shimada, T.; Suzuki, M.; Sano, H.; Adachi, K.; Carmichael, W.W. (1995). Two cyclic peptides, anabaenopeptins, a third group of bioactive compounds from the cyanobacterium Anabaena flos-aquae NRC-525-17. Tetrahedron Lett., 36 (9), 15111514.

15. Harada, K-i.; Mayumi, T.; Shimada, T.; Suzuki, M.; Kondo, F.; Watanabe, M.F. (1993). Occurrence of four depsipeptides, aeruginopeptins, together with microcystins from toxic cyanobacteria. Tetrahedron Lett., 34(38), 6091-6094.

16. Huszar, V.L.M.; Silva, L.H.S.; Marinho, M.; Domingos, M.; Sant Anna, C.L. (2004). Cyanoprokaryote assemblages in eight productive tropical Brazilian waters. Hydrobiologia, 424, 67-77.

17. Ishida, K.; Matsuda, H.; Murakami, M.; Yamaguchi, K. (1997). Micropeptins $478-\mathrm{K}$ and $-\mathrm{B}$, plasmin inhibitors from the cyanobacterium Microcystis aeruginosa. J. Nat. Prod., 60, 184-187.

18. Jardim, F.A.; Fonseca, Y.M.F.; Vianna, L.N.L.; Azevedo, S.M.F.; Ciscotto, P.H.C. (2001). Primeira ocorrência de cianobactérias tóxicas em um reservatório da COPASA - Minas Gerais - Brasil. BIOS, Cadernos do Departamento de Ciências Biológicas da PUC Minas, 9 (9), 83-91.

19. Komárek, J.; Anagnostidis, K. (2005). Cyanoprokaryota 2. Teil: Oscillatoriales. In: Büdel, B., Gärtner, G., Krienitz, L., Schagerl, M. (eds). Süsswasserflora von Mitteleuropa 19 (2), Elsevier/Spektrum Akademischer Verlag, Heidelberg, p. 1-759.

20. Komárek, J.; Anagnostidis, K. (1999). Cyanoprokaryota 1. Teil: Chroococcales. In: Ettl, H., Gärtner, G., Heynig, H., Mollenhauer, D. (eds). Süsswasserflora von Mitteleuropa 19 (1), Gustav Fischer, Jena, p. 1-548.

21. Komárek, J.; Anagnostidis, K. (1989). Modern approach to the classification system of cyanophytes 4 - Nostocales. Algol. Stud., 82 (3), 247-345.

22. Kuroda, E.K.; Minillo, A.; Rocha, O.; Filho, E.R.; Bernardo, L.D. (2007). Acute toxicity evaluation for a Microcystis spp. strain by bioassay with male Swiss albino mice. Eng. Sanit. Ambient., 12, 24-31.

23. Lawton, L.; Beattie, K.A.; Hawser, S.P.; Campbell, D.L.; Codd, G.A. (1994). Evalution of assay methods for determination of cyanobacterial hepatotoxicity. In: Codd, G.A., Jefferies, T.M., Keevil,
C.W., Potter, E. (eds). Detection methods for cyanobacterial toxins. Special Publication. No. 149, The Royal Society of Chemistry, Cambridge, UK, p. 347-366.

24. Magalhães, V.F.; Soares, R.M.; Azevedo, S.M.F.O. (2001). Microcystin contamination in fish from the Jacarepaguá Lagoon (Rio de Janeiro, Brazil): ecological implication and human health risk. Toxicon, 39, 1077-1085.

25. Matthiensen, K.A.; Yunes, J.S.; Codd, G.A. (1999). Ocorrência, distribuição e toxicidade de cianobactérias no estuário da Lagoa dos Patos, RS. Rev. Bras. Biol., 59 (3), 361-373.

26. MacKintosh, C.; Beattie, K.A.; Klumpp, S.; Cohen, P.; Codd, G.A. (1990). Cyanobacterial microcystin-LR is a potent and specific inhibitor of protein phosphatases 1 and $2 \mathrm{~A}$ from both mammals and higher plants. FEBS Lett., 264 (2), 187-192.

27. Minillo, A.; Ferreira, A.H.F.; Yunes, J.S. (2000). Detecção de microcistinas em florações de Microcystis aeruginosa no estuário da lagoa dos Patos, RS, entre 1997 e 1998. Atlântica, 22, 81-93.

28. Molica, R.J.R.; Oliveira, E.J.A.; Carvalho, P.V.V.C.; Costa, A.N.S.F.; Cunha, M.C.C.; Melo, G.L.; Azevedo, S.M.F.O. (2005). Occurrence of saxitoxins and an anatoxin-a(s)-like anticholinesterase in a Brazilian drinking water supply. Harm. Alg., 2, 743-753.

29. Monserrat, J.M.; Yunes, J.S.; Bianchini, A. (2001). Effects of Anabaena spiroides aqueous extracts on the AChE activity of aquatic species. Environ. Toxicol. \& Chem., 20 (6), 1228-1235.

30. Mur, L.R.; Skulberg, O.M.; Utkilen, H. (1999). Cyanobacteria in the environment. In: Chorus, I., Bartram, J. (eds). Toxic cyanobacteria in water. A guide to their public health consequences, monitoring and management. E \& FN Spon, New York, USA, p. 15-37.

31. Murakami, M.; Suzuki, S.; Itou, Y.; Kodani, S.; Ishida, K. (2000). Anabaenopeptins, potent carboxypeptidase-A inhibitors from the cyanobacterium Aphanizomenon flos-aquae. J. Nat. Prod., 63, 12801282.

32. Murakami, M.; Ishida, K.; Okino, T.; Okita, Y.; Matsuda, H.; Yamaguchi, K. (1995). Aeruginosins 98-A and B, trypsin inhibitors from the blue-green algae Microcystis aeruginosa (NIES-98). Tetrahedron Lett., 36 (16), 2785-2788.

33. Porfírio, Z.; Ribeiro, M.P.; Estevam, C.S.; Houly, R.L.S.; Santana, E.G. (1999). Hepatosplenomegaly caused by an extract of cyanobacterium Microcystis aeruginosa bloom collected in the Manguaba Lagoon, Alagoas-Brazil. Rev. Microbiol., 30, 278-285.

34. Pyo, D.; Shin, H. (2002). Extraction and analysis of microcystins RR and LR in cyanobacteria using a cyano cartridge. J. Biochem. Biophys. Meth., 51, 103-109.

35. Repka, S.; Koivula, M.; Harjunpä, V.; Rouhiainen, L.; Sivonen, K. (2004). Effects of phosphate and light on growth of bioactive peptide production by the cyanobacterium Anabaena strain 90 and its anabaenopeptilide mutant. Appl. Environ. Microbiol., 70 (8), 45514560 .

36. Reshef, V.; Carmeli, S. (2001). Protease inhibitors from a water bloom of the cyanobacterium Microcystis aeruginosa. Tetrahedron, 57, 2885-2894.

37. Sano, T.; Usui, T.; Ueda, K.; Osada, H.; Kaya, K. (2001). Isolation of new protein phosphatase inhibitors from two cyanobacteria species, Planktothrix sp. J. N. Prod., 64, 1052-1055.

38. Sant' Anna, C.L; Azevedo, M.T.P. (2000). Contribution to the knowlwdge of potentially toxic cyanobacteria from Brazil. Nova Hedwigia, 71, 359-385.

39. Shin, H.J.; Matsuda, H.; Murakami, M.; Yamaguchi, K. (1997). Aeruginosins 205A and -B, serine protease inhibitory glycopeptides from the cyanobacterium Oscillatoria agardhii (NIES-205). J. Org. Chem., 62, 1810-1813.

40. Sotero-Santos, R.B.; Silva, C.R.S.E.; Verani, N.F.; Nonaka, K.O.; Rocha, O. (2006). Toxicity of a cyanobacteria bloom in Barra Bonita Reservoir (Middle Tietê River, São Paulo, Brazil). Ecotoxicol. Environ. Saf., 64, 163-170. 
41. Tundisi, J.G.; Matsumura-Tundisi, T. (1992). Eutrophication of lakes and reservoirs: a comparative analysis, case studies, perspectives. In: Cordeiro-Marino, M., AZEVEDO, M.T.P., Sant'Anna, C.L., Tomita, N.Y., Plastino, E.M. (ed.). Algae and environment: a general approach. Sociedade Brasileira de Ficologia, São Paulo, BR, p. 1-33.

42. Utkilen, H.; Skulberg, O.M.; Skulberg, R.; Gjølme, N.; Underdal, B. (2001). Comparison of cyanotoxin occurrence in different countries. In: Chorus, I. (ed). Cyanotoxins. Occurrence, cause, consequences, Springer-Verlag, Berlin, Deutschland, p. 46-82.

43. Vieira, J.M.S.; Azevedo, M.T.P.; Azevedo, S.M.F.O.; Honda, R.Y.; Corrêa, B. (2005). Toxic cyanobacteria and microcystin concentrations in a public water supply reservoir in the Brazilian Amazonia region. Toxicon, 45, 901-909.

44. Welker, M.; Brunke, M.; Preussel, K.; Lippert, I.; von Döhren, H. (2004). Diversity and distribution of Microcystis (Cianobacteria) oligopeptide chemotypes from natural communities studied by singlecolony mass spectrometry. Microbiology, 150, 1785-1796.
45. Welker, M.; Mar]álek, B.; Šejnohová, L.; von Döhren, H. (2006). Detection and identification of oligopeptides in Microcystis (cyanobacteria) colonies: toward an understanding of metabolic diversity. Peptides, 27, 2090-2103.

46. Yuan, M.; Namikoshi, M.; Ohtsuki, A.; Rinehart, K.L.; Sivonen, K.; Watanabe, M.F. (1999). Low-energy collisionaly activated decomposition and structural characterization of cyclic heptapeptide microcystins by electrospray ionization mass spectrometry. J. Mass Spectrom, 34, 33-43.

47. Yunes, J.S.; Salomon, P.S.; Matthiensen, A.; Beattie, K.A.; Raggett, S.L.; Codd, G.A. (1996). Toxic blooms of cyanobacteria in the Patos Lagoon Estuary, southern Brazil. J. Aquat. Ecosys. Health, 5, 223 229.

48. Zagatto, P.A.; Aragão, M.A.; Domingues, D.F.; Buratini, S.V.; Araujo, R.P.A. (1998). Avaliação ecotoxicológica do reservatório do Guarapiranga, SP, com ênfase à problemática das algas tóxicas e algicidas. Anais do Congresso Latino-Americano de Ficologia, São Paulo, SP, p. 63-81. 